\title{
The first non-avian theropod from the Czech Republic
}

\author{
Daniel Madzia \\ Acta Palaeontologica Polonica 59 (4), 2014: 855-862 doi: http://dx.doi.org/10.4202/app.2012.0111
}

All currently known theropod specimens from the Czech Republic have been attributed to the crown clade Aves. However, an archosaur tooth in the Institute of Geological Sciences (Faculty of Science, Masaryk University), labelled as Teleosaurus, belongs to a non-avian theropod. The tooth comes from the Upper Jurassic (Oxfordian) carbonate rocks of Švédské šance (Brno-Slatina) and represents the first terrestrial vertebrate known from the Jurassic of the Czech Republic. The tooth is described here in detail and compared to anatomical descriptions of taxa, and comprehensive sets of quantitative and qualitative data. On the basis of the comparisons, it is concluded that the Moravian theropod was likely a basal representative of the clade Tetanurae, whose members were abundant in Europe during the Middle to Late Jurassic.

Key words: Dinosauria, Theropoda, theropod tooth, Jurassic, Oxfordian, Czech Republic.

Daniel Madzia [daniel.madzia@gmail.com], Institute of Geological Sciences, Masaryk University, 2 Kotlářská, 61137 Brno, Czech Republic; current address: Institute of Palaeobiology, Polish Academy of Sciences, ul. Twarda 51/55, 00-818 Warszawa, Poland.

This is an open-access article distributed under the terms of the Creative Commons Attribution License (for details please see creativecommons.org), which permits unrestricted use, distribution, and reproduction in any medium, provided the original author and source are credited.

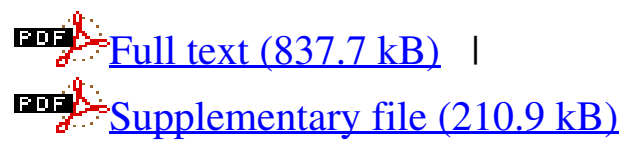

